\title{
From X-rays to Biomolecular Structure: D. Hodgkin, R. Franklin and A. Yonath \\ Gonçalves-Maia, R.
}

Rev. Virtual Quim., 2012, 4 (6), 818-839. Data de publicação na Web: 26 de outubro de 2012

\author{
http://www.uff.br/rvq
}

\begin{abstract}
Following the discovery of X-rays by Wilhelm Röntgen and Max von Laue's discovery of X-ray diffraction by crystals, William and Lawrence Bragg made it possible to calculate the positions of the atoms within a crystal from the way in which an X-ray beam is diffracted by a crystal lattice. Since then, several researchers have applied this powerful technique in the study of many molecules of life, such as proteins, vitamins and hormones. In this interdisciplinary field, two women played a very important role, viz. Dorothy Hodgkin (Nobel Prize, 1964) and Rosalind Franklin. Nowadays, Ada Yonath (Nobel Prize, 2009) follows a similar line of research. We will emphasize the extraordinary work of these scientists.
\end{abstract}

Keywords: X-ray diffraction; Biomolecular Structure; Dorothy Hodgkin; Rosalind Franklin; Ada Yonath.

\section{Dos Raios-X à Estrutura Biomolecular: D. Hodgkin, R. Franklin e A. Yonath}

Resumo: Após a descoberta dos Raios X por Wilhelm Röntgen, após a descoberta da difração dos Raios $\mathrm{X}$ pelos cristais por Max von Laue, William e Lawrence Bragg demonstraram como calcular as posições dos átomos num cristal a partir da forma como um feixe de Raios $\mathrm{X}$ é difratado pela rede cristalina.

Desde então foram vários os investigadores que aplicaram esta poderosa técnica ao estudo de muitas moléculas da vida, tais como proteínas, vitaminas e hormonas. Nesta área interdisciplinar, duas mulheres desempenharam um importante papel: Dorothy Hodgkin (Prémio Nobel, 1964) e Rosalind Franklin. Na atualidade, Ada Yonath (Prémio Nobel, 2009) prossegue uma linha de investigação semelhante. Evidenciaremos o extraordinário trabalho destas cientistas.

Palavras-chave: Difração de Raios X; Estrutura biomolecular; Dorothy Hodgkin; Rosalind Franklin; Ada Yonath.

\footnotetext{
* Rua Fotógrafo Arcelino, 26, 2ㅇ Esq-Frt., 4705-095 Braga, Portugal. Raquel Gonçalves-Maia is a retired Professor of Chemistry from the Faculty of Sciences of the University of Lisbon, Portugal.

Mrmcgonc@gmail.com

DOI: $\underline{10.5935 / 1984-6835.20120059}$
} 
Volume 4, Número 6

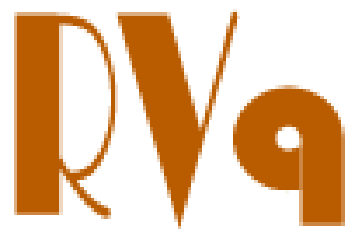

Novembro-Dezembro 2012

Revista Virtual de Química

ISSN 1984-6835

\section{From X-rays to Biomolecular Structure: D. Hodgkin, R. Franklin and A. Yonath \\ Raquel Gonçalves-Maia}

Rua Fotógrafo Arcelino, 26, 20 Esq-Frt., 4705-095 Braga, Portugal. Raquel Gonçalves-Maia is a retired Professor of Chemistry from the Faculty of Sciences of the University of Lisbon,

Portugal.

*rmcgonc@gmail.com

Recebido em 10 de outubro de 2012. Aceito para publicação em 14 de outubro de 2012

1. Diffraction of X-rays by crystals

2. A "mother of three" - Dorothy Crowfoot Hodgkin

3. "Alarmingly clever" - Rosalind Elsie Franklin

4. The "curly haired" Israeli crystallographer - Ada E. Yonath

5. Final Comments

\section{Diffraction of X-rays by crystals}

Wilhelm Röntgen discovered X-rays just before the end of the $19^{\text {th }}$ century. And, for the discovery of these remarkable rays, in 1901 he was awarded the first Nobel Prize for Physics. Since than, $\mathrm{X}$-rays have contributed to some of the most important advances in science.

Röntgen's discovery gave crystallographers a powerful tool to "see" particles inside a crystal. The exploration of the molecular structure of a crystalline solid started almost immediately. ${ }^{2-5}$

Max von Laue received the Nobel Prize for Physics in 1914 for his discovery of the diffraction of $\mathrm{X}$-rays by crystals. This technique was applied to simple inorganic compounds like copper sulfate (pentahydrate) or sodium chloride. An X-ray "photograph" with several spots was the result; then, it was used for interpretation in structural terms. ${ }^{6}$

In 1915, William Henry Bragg and William Lawrence Bragg, father and son, won the Nobel Prize in Physics for their analysis of crystal structures by means of $\mathrm{X}$-ray diffraction. An important relationship - the Bragg equation - was then established,

$$
\mathrm{n} \lambda=\mathbf{2} \mathrm{d} \sin \theta
$$

describing the wavelength $(\lambda)$ of the $X$-rays as a function of the distance between planes into the crystalline structure; $\theta$ is the incidence angle of the X-ray beam. ${ }^{8-9}$ 
Gonçalves-Maia, $R$.

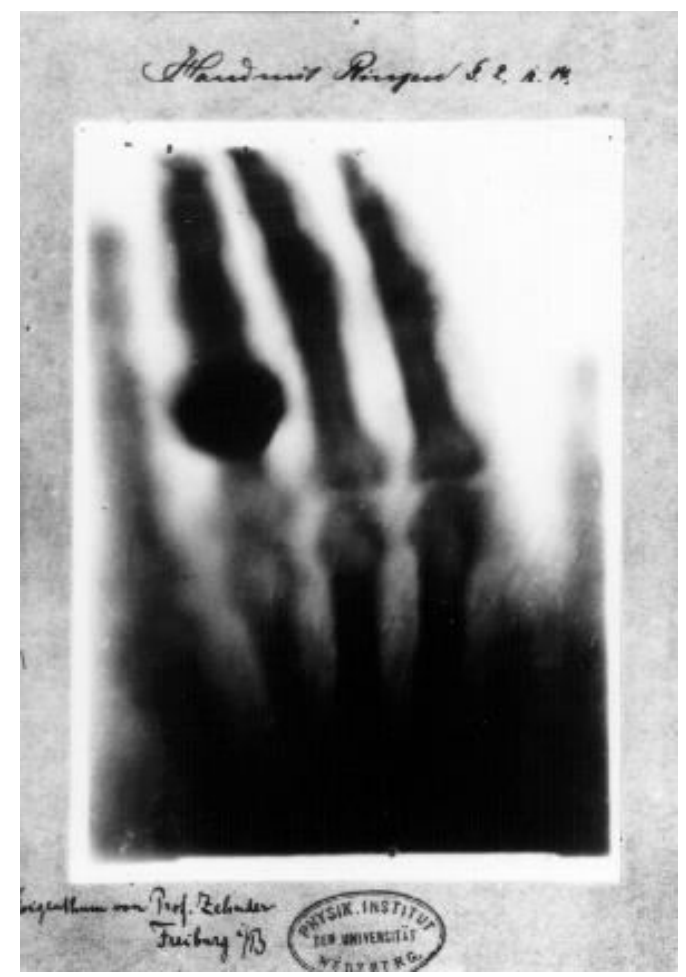

Figure 1. Hand with Rings. X-Ray by Wilhelm Röntgen of the left hand of his wife Anna Bertha Ludwig (1895) ${ }^{1}$
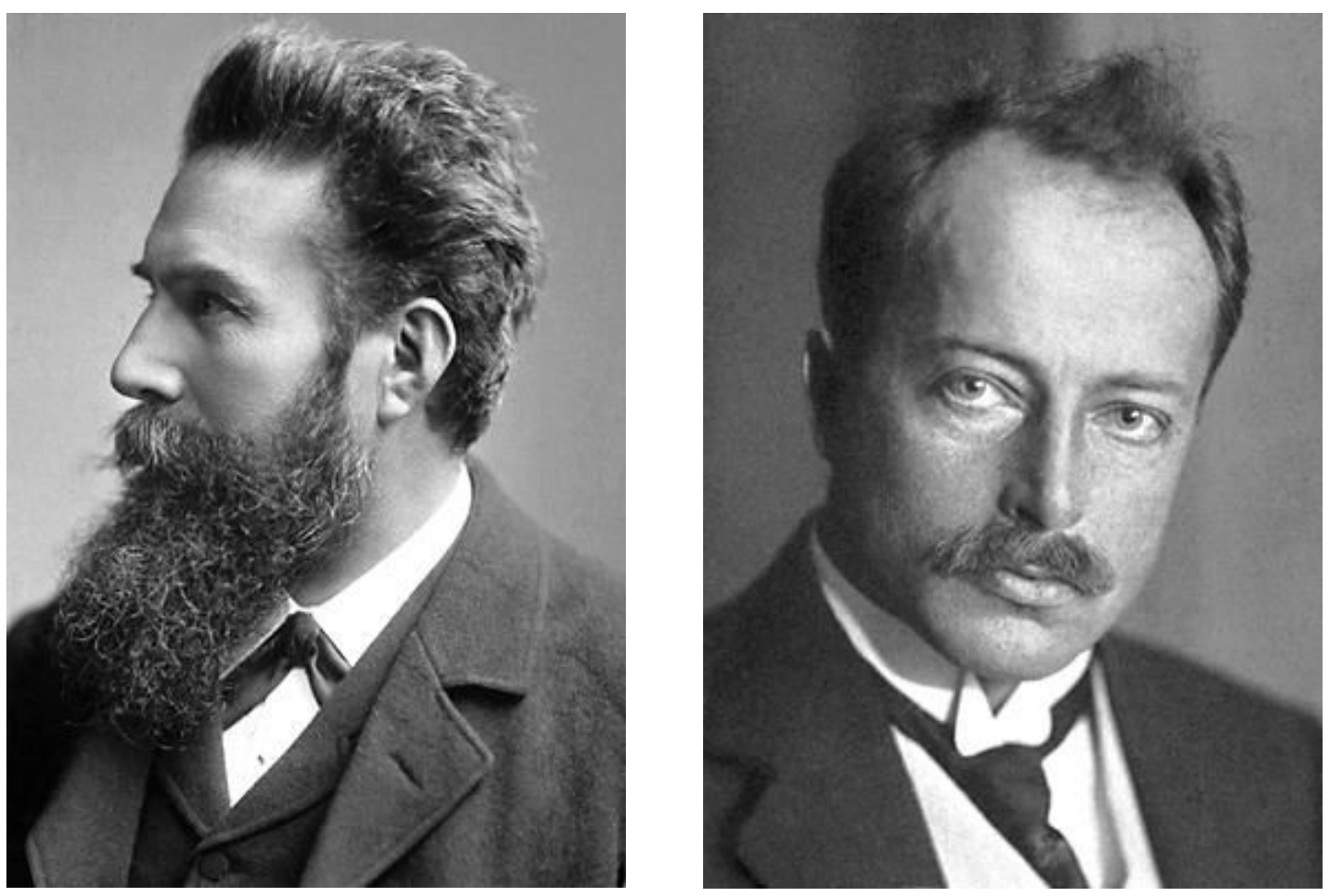

Figure 2. Nobel pictures of Wilhelm Röntgen (1901) and Max von Laue (1914). Nobel foundation ${ }^{7}$ 

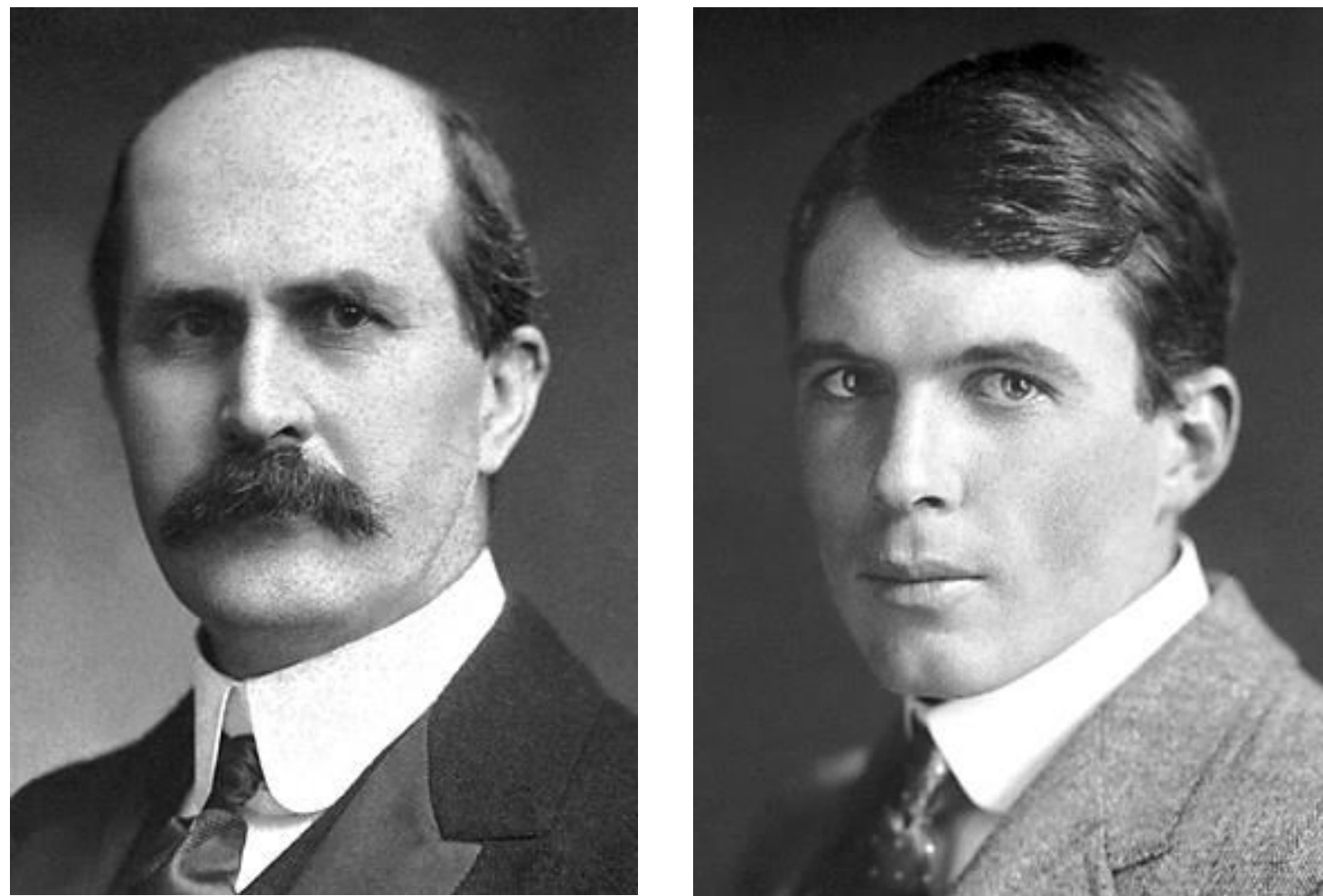

Figure 3. Nobel pictures of William Bragg (1915) and Lawrence Bragg (1915). Nobel foundation $^{10}$

However, structure determination, even for a simple compound, is far more complicated than what we are presenting here; wave phase and scattering factors, for instance, play a decisive role. Contributions from several scientists showed that diffraction diagrams could be transformed into an electron density map that enables to locate the different atoms of the tridimensional molecular structure. In this context, the name of Arthur Lindo Patterson should be mentioned. ${ }^{11-12}$

With earlier diffractometers, the diffraction data had to be measured manually point-by-point, which was a terrible time consuming task and, thus, a serious limitation to its use. Even so, John Desmond Bernal, after developing the experimental method and the mathematical treatment of determining crystal structure, started applying crystallographic techniques to organic molecules in the late twenties. It was at Cambridge that, together with Dorothy
Hodgkin, he took the first X-ray photographs of a protein crystal - pepsin. ${ }^{13}$

Bernal was one of the best (and controversial) scientists in the United Kingdom. His friends (and not just his friends) called him, most appropriately, the "Sage". He was, no doubt, one of the greatest scientific scholars of all times. "His greatest gift was his power to inspire others", said Dorothy Hodgkin. ${ }^{15-17}$ Later, Desmond Bernal became a professor of Physics at the Birkbeck College of the University of London. Max Perutz arrived in 1936 and started his work on hemoglobin. ${ }^{18,19}$ Afterwards, Aaron Klug worked on ribonuclease ${ }^{20}$ and Rosalind Franklin joined them and worked on the virus structure.

But who were Dorothy Hodgkin and Rosalind Franklin? Why were they so important in the context of Structural Biochemistry? ${ }^{21}$ 


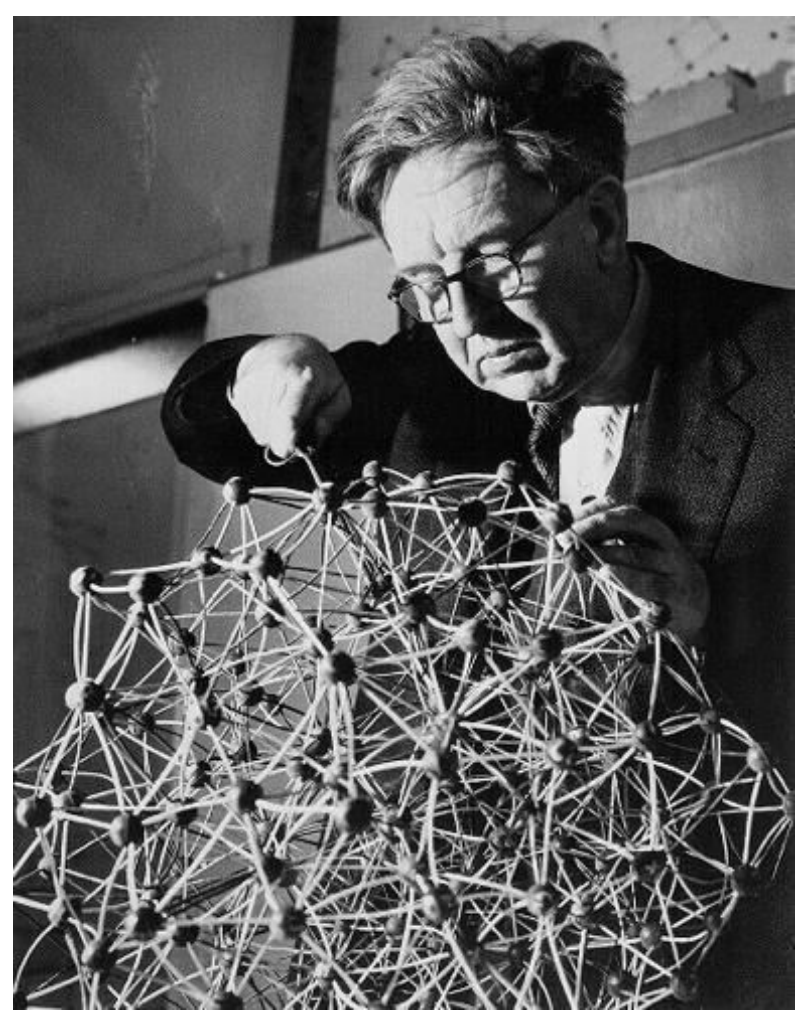

Figure 4. J. D. Bernal working at Birkbeck (1938-1968). Head of Physics and then Crystallography. Copyright Birkbeck, University of London ${ }^{14}$

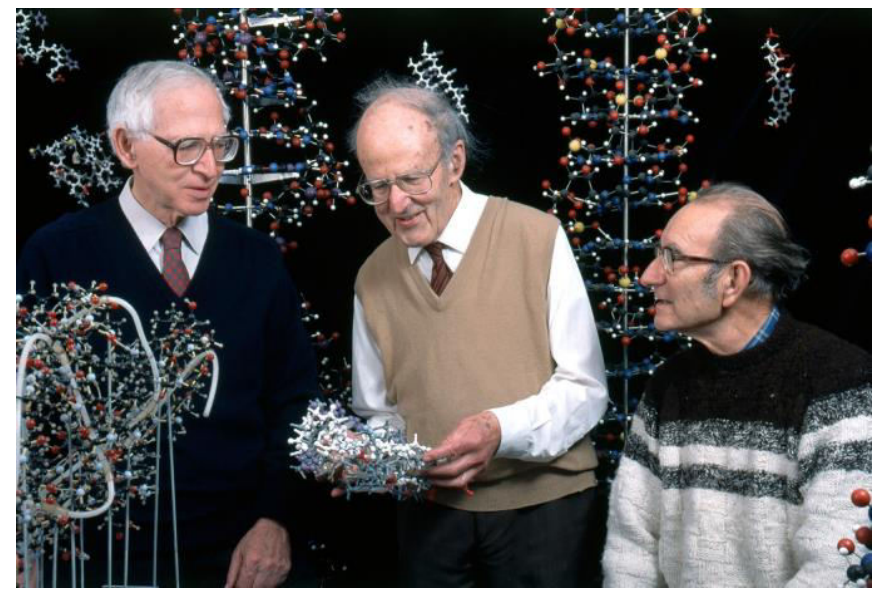

Figure 5. Aaron Klug, Max Perutz and César Milstein in the model room at LMB, c. 1999. Courtesy of MRC Laboratory of Molecular Biology, Cambridge, UK

Dorothy Crowfoot Hodgkin was a fragile woman, "mother of three", suffering from rheumatoid arthritis, a British scientist who managed to solve the structure of a hundred of steroids, penicillin, vitamin $B_{12}$ and even insulin. Amazing! $!^{22,23}$

Rosalind Elsie Franklin was a brilliant researcher, born in London in a British Jewish family. She performed "the most beautiful $X$ ray photographs of any substance ever taken", said the "Sage". It was her crucial photograph of DNA that allowed achieving one of the greatest scientific discoveries of the twentieth century, the double-helix 
structure of DNA. ${ }^{24-25}$

Recently, the Nobel Prize in Chemistry was awarded to Ada Yonath, jointly with Thomas Seitz and Venkaraman Ramakrishnan. ${ }^{26}$ Ada E. Yonath, the "curly haired" Israeli crystallographer, thought a lot about the hibernation of polar bears. Would it be possible to "hibernate" ribosomes in order to crystallize them? Indeed it was. Ribosomes, those large, complex and curled structures required for protein building, were finally decrypted.

\section{A "mother of three" - Dorothy Crowfoot Hodgkin}

When Dorothy Mary Crowfoot passed for the first time the door of the X-ray crystallography laboratory at the University of Oxford in England, she was carrying the following words with her: "... Advancement of Science." It was September 1931, at the beginning of her research program. The laboratory was set in a renewed room of the University Museum. At the entrance one could see a plate announcing it was at that location that the irreverent Thomas Huxley defended Charles Darwin's theory of evolution confronting with the very respectable and conservative Bishop of Oxford, Samuel Wilberforce. The event had taken place in 1860 in a celebrated meeting of the British Association for the Advancement of Science. However, perhaps Dorothy could not even imagine how far advancement would lead her... ${ }^{22,23,27,28}$

Dorothy Crowfoot was an enthusiast of $X$ ray crystallography since she was very young. As a part of her BA Honors course in Chemistry at the University of Oxford Somerville College, the topic of her original research was to find the tridimensional structures of thallium compounds. Although nowadays these molecules are taken as "simple", taking into account their number of atoms and bonds, in 1931 this was not the case, let alone for X-ray diffraction studies. It was quite a challenge! However, Dorothy had an innate insight for the tridimensional through two-dimensionality.

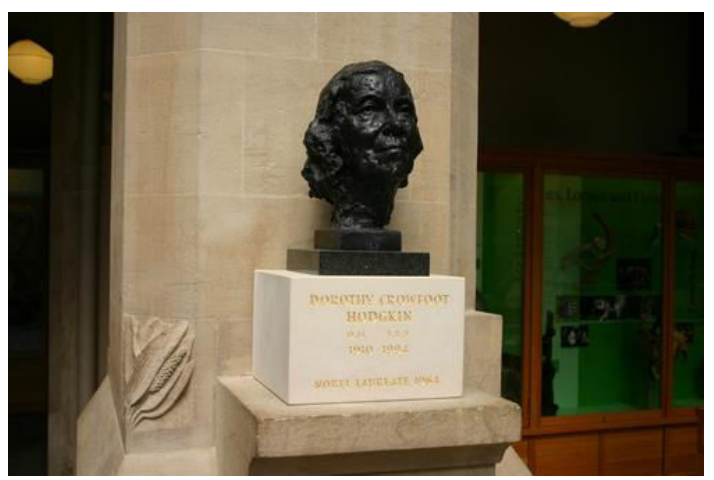

Figure 6. Dorothy Crowfoot Hodgkin's bust inside Oxford University Museum of Natural History. Photo by Luca Borghi for Himetop - The History of Medicine Topographical Database. Courtesy of the author ${ }^{29}$

Recently, during the celebrations of the hundredth anniversary of her birth, a bronze head of Dorothy was set inside the Oxford University Museum of Natural History. The bust was unveiled by Dorothy's little sister
Diana (Dilly) Rowley.

Dorothy Mary Crowfoot was born on May 12, 1910 and was the eldest of the four daughters of Grace Mary Hood (Molly) ${ }^{30}$ and John Winter Crowfoot, ${ }^{31}$ a British couple. At 
the time they were living in Cairo, Egypt, where her father worked as an archaeologist. Later, in England, as a young student she attended the Leman School in Beccles (Suffolk). Chemistry entranced her. The mother, in turn, fueled her daughter's passion. On a visit to London, she bought her the publications, suitably adapted to children, of the lectures William Bragg had delivered at the Royal Institution, between 1923 and 1925. Their titles were "Concerning the Nature of Things" and "Old Trades and New Knowledge". Mother and daughter read the books together and were fascinated. $X$ rays revealed the structure of inorganic solids! One wonders if it has been since then that Dorothy imagined one could also extrapolate this method to study biological materials. And even more, having John Desmond Bernal as her supervisor!

After her graduation in Oxford with the highest mark, "first-class", Dorothy Crowfoot continued investigating the structures of various compounds, now as a member of Desmond Bernal's group in Cambridge. She could take advantage of adequate equipment and of an excellent working environment. Their research was one of a very high scientific standard, with great openness of ideas and discussion of results. And humor was also an important part of their work... At Bernal's suggestion, Dorothy registered at the Cambridge University as a PhD student.

In Cambridge, she had an excellent workout. $^{32}$ Crystallography applied to structure determination was a truly interdisciplinary field, which implied to merge knowledge coming from Chemistry, Biology, Biochemistry... and also Mathematics and Physics. A challenge! Dorothy learned that the crystals had to be studied in their mother liquor, without letting them dry; that isomorphism was crucial in this study; that it was necessary to compare the diffraction pattern of the crystal with that of one isomorphic analog, i.e. a derivative containing a single different atom, a heavier one.
Meanwhile, the University of Oxford authorities decided to contact Dorothy. They offered her a research grant with the eventuality of becoming permanent, thus meaning independence in her research... and some teaching responsibility. She dislikes this last part, teaching at the undergraduate level never enthused her. The offer was very interesting, a real job offer! Everything retains her in Cambridge... Nevertheless, she accepted and began traveling with some regularity between Oxford and Cambridge.

Whilst working at Cambridge and Oxford during the 30 's, Dorothy unriddled the structure of a hundred sterols (cholesterol is probably the most well-known). In other words, she determined the position of atoms in space, distances, angles and their binding energies within the molecule. She also determined the functionality of certain atom groups.

During those years, Dorothy still found time to fall in love with Desmond Bernal, the "Sage" and, then, also to get married with Thomas Hodgkin, from whom she had three children: Luke Howard, Elisabeth (Lizzie) and John Robin Tobias (Toby). By getting married Dorothy did not resign. Thomas accepted her decision. He decided early in the marriage that his wife was the more creative of the two. $^{33}$ Wouldn't she resign now, being a mother of three children? Her own sister Dilly questioned her when Luke was born: "Now do you want the child more or Somerville more?" Of course she wanted both! Certainly yes, though with different types of love. An old sentence of hers sums up well this situation: "Don't you understand, I've got to know!"22,23

Soon after Luke was born, Dorothy experienced her first acute arthritis attack, an illness that is characterized by the inflammation of the synovial membrane of the joints leading to the emergence of nodes and progressive rigidity. Never having given in to her disease, Dorothy lived until she was 84. "My hands think", she used to say. 


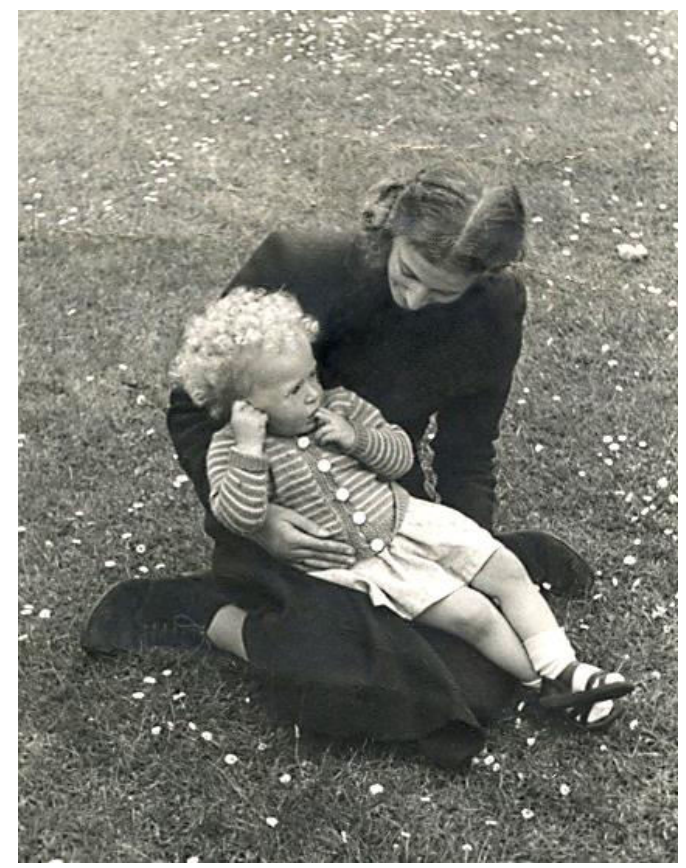

Figure 7. Dorothy Hodgkin with her daughter Elizabeth (Lizzie). Courtesy of Elizabeth Hodgkin

This fragile woman scientist achieved the prowess of solving the intricate structure of penicillin, a fundamental antibiotic in the combat of infections, throughout and after World War II. Later, she also solved the structure of vitamin $B_{12}-181$ atoms! - a very complex and important molecule since its deficiency causes pernicious anemia with related neurological alterations and weakness, and may even lead to fatal convulsions. Such finding further justified the prescription of balanced diets and the design of new compounds aimed at laboratorial synthesis. ${ }^{34,35}$

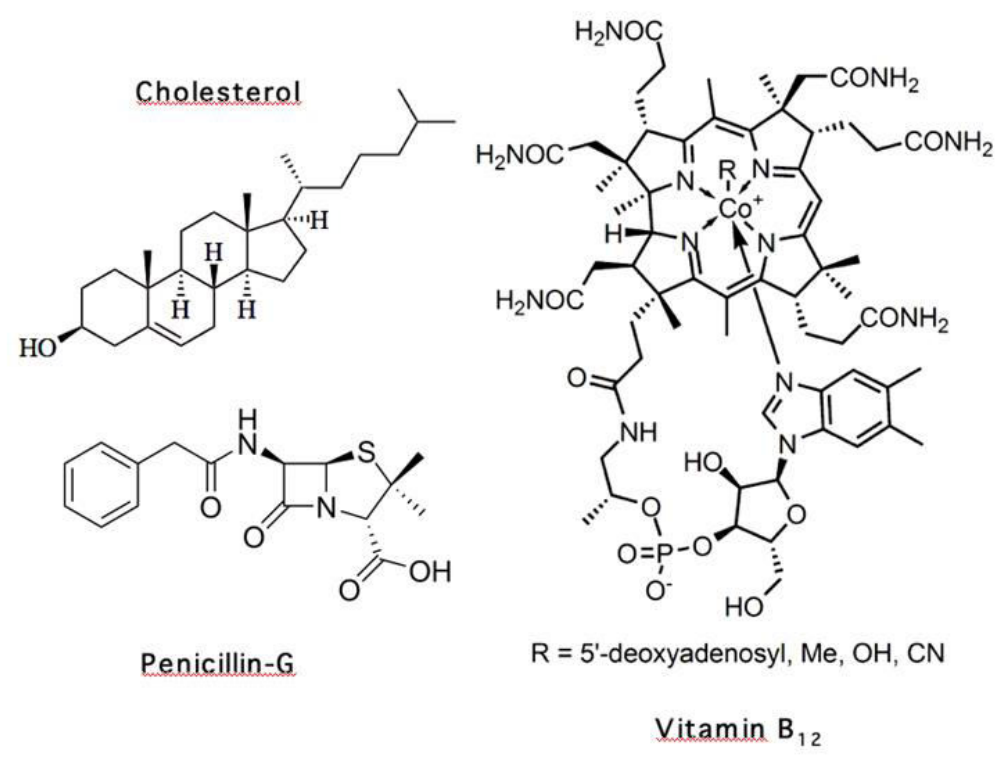

Figure 8. Structures of Cholesterol, Penicillin and Vitamin $B_{12}{ }^{36}$ 
Dorothy Crowfoot Hodgkin "had to" receive the Nobel Prize for Chemistry. And indeed she did. Unshared, the sole winner... She was awarded the Nobel Prize "for her determinations by $X$-ray techniques of the structures of important biochemical substances". ${ }^{37-39}$ Nobel Prize awarded to "mother of three", as announced by the Daily
Telegraph;" "Nobel Prize Winner is a Grandmother", as announced by the New York Times. ${ }^{41}$ Dorothy was 54 years old. Although her hands, her feet and her knees were extremely swollen and her mobility was severely compromised, nothing jeopardized this women's resilience.

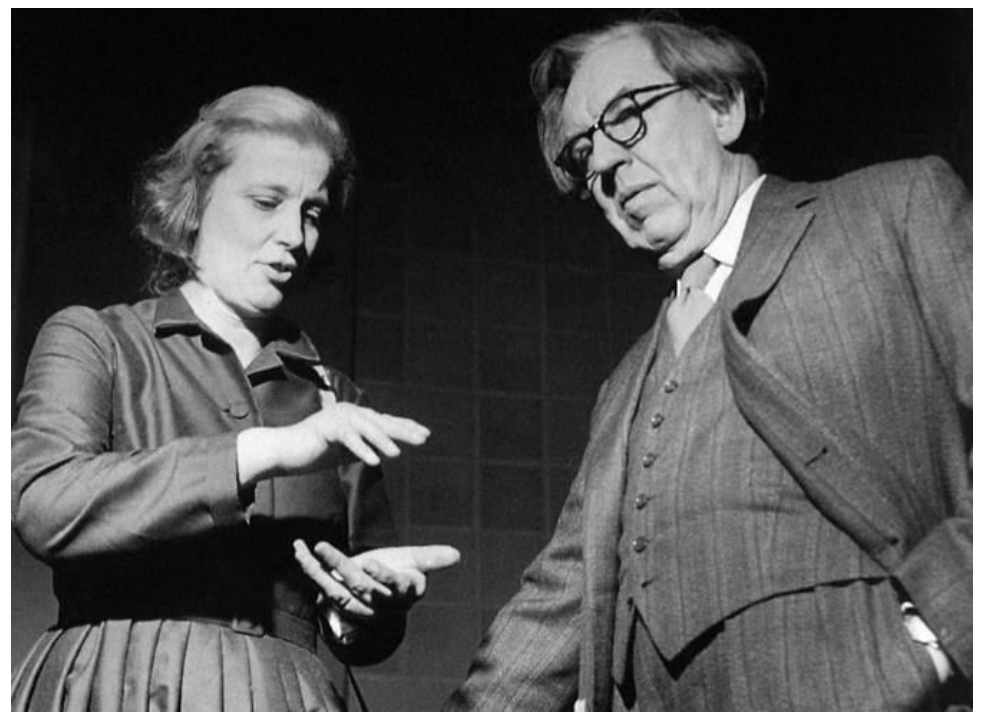

Figure 9. John Desmond Bernal and Dorothy Crowfoot Hodgkin. Copyright Birkbeck, University of London ${ }^{42}$

From a very early stage, Dorothy showed a preference for the insulin molecule. Throughout three decades of persistent study she determined all the intricacies of the multiple structure of insulin (784 atoms in its basic structure!), which led to the unprecedented understanding of the function of this vital pancreatic hormone who's failure disables sugar metabolism, thus leading to the overcome of diabetes. At the end of the 1960's, all those who directly or indirectly contributed to solve this structure, shared this discovery as co-authors or through acknowlegement. ${ }^{43-44}$ The journal Nature published the memorable article. The model still underwent some refinements with respect to spatial coordinates. In 1971, again in Nature, the new results emerged with a structural resolution of high accuracy. But one should not think that Dorothy stopped at that stage. She would not get rid of the subject before all details were fully identified. In 1988, she finally published her last article on insulin. The paper had 87 pages, 13 authors and a structural resolution with the precision of $1.5 \AA^{45}$

Emphasis must be put on the fact that, throughout her life, all investigation carried out by Dorothy was based on scientific cooperation. Although she was a physicalchemist her research fell upon the molecules of life (Biochemistry), the progress in Mathematics and Computer Science having had a great influence in her success. ${ }^{46} \mathrm{Her}$ collaborators were from all around the world. From United Kingdom, of course, but also from USA, India, China, Australia, New Zealand... ${ }^{47-50}$

Dorothy was always a pacifist, she devoted much of her last years traveling and giving lectures for the cause of world peace. ${ }^{51}$ 


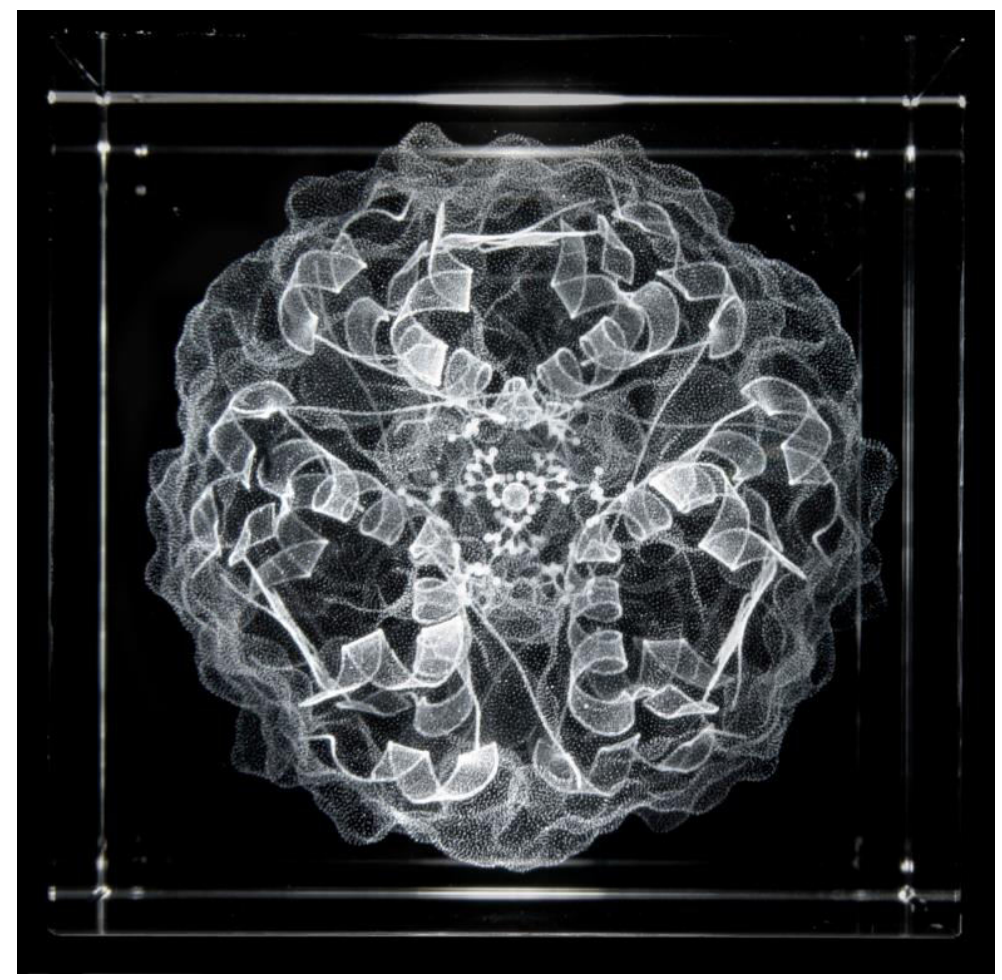

Figure 10. Insulin Crystal, glass paperweight 3D laser sculpture by Bathsheba Grossman.

Courtesy of the author

Many and well deserved were the honors received by Dorothy. The first major award of her brilliant career was being elected Fellow of the Royal Society in 1947 and, soon after, Fellow and Chemistry Tutor of Somerville. She was awarded the Royal Medal of the Royal Society in 1956 - the first one that was awarded to a woman. She was appointed Wolfson Research Professor at the Royal Society (1960). And, beyond the Nobel Prize, it is very important to highlight the concession of the Order of Merit, assigned by Her Royal Majesty Queen Elizabeth II, the highest award that may be given to a British citizen, an award that may only be beard by 24 citizens, simultaneously. ${ }^{22,23}$

\section{3. "Alarmingly clever" - Rosalind Elsie Franklin}

Rosalind Elsie Franklin was the second child of a family of five. She was born on July 1920 , in London, from the upper middle class
Anglo-Jewish couple Ellis Franklin and Muriel Waley. This was a heavy heritage for a very determined girl like Rosalind. She always knew where she wanted to go. "Faith is essential to success in life", she wrote to her father; and, by "faith", she meant facts, experiences and experiments... $2,24,25,33$ Recently, her younger sister Jenifer Glynn published a family memoir where she offers us an insider portrait of Rosalind's life. ${ }^{52}$

When Rosalind was six, her aunt Mamie Bentwich noted that she preferred doing arithmetic to playing in the sand, that she was "alarmingly clever" - not "amazingly", not "remarkably", not "incredibly"... but "alarmingly"! At the age of eleven she entered the St. Paul's Girls' School. She had a bad-temper, but she was delighted with science; and also with sports, swimming and, later, mountain climbing.

Science and the University were her interests. Rosalind had a first in the Cambridge examination in Chemistry. Her father never opposed her going to Newnham 
College, Cambridge. He was proud and just asked her to keep him informed of her progress. The University of Cambridge had admitted women since 1869 and Jews since 1871.

There was an ongoing world war but not less work in Cambridge. She works hard in the University, learning about the nature of the chemical bonds, according to Linus Pauling. She learned about proteins and the alpha-helix. She got deeper and deeper into crystallography, Bragg's achievements, the unit cell of the crystal, the methods of approaching structure. She was thrilled about the spots in the photographic plate that X-ray diffraction made after crossing the crystal. "Absorption of X-rays depends only on the number and kind of atoms present", she wrote in her notebook. ${ }^{24}$

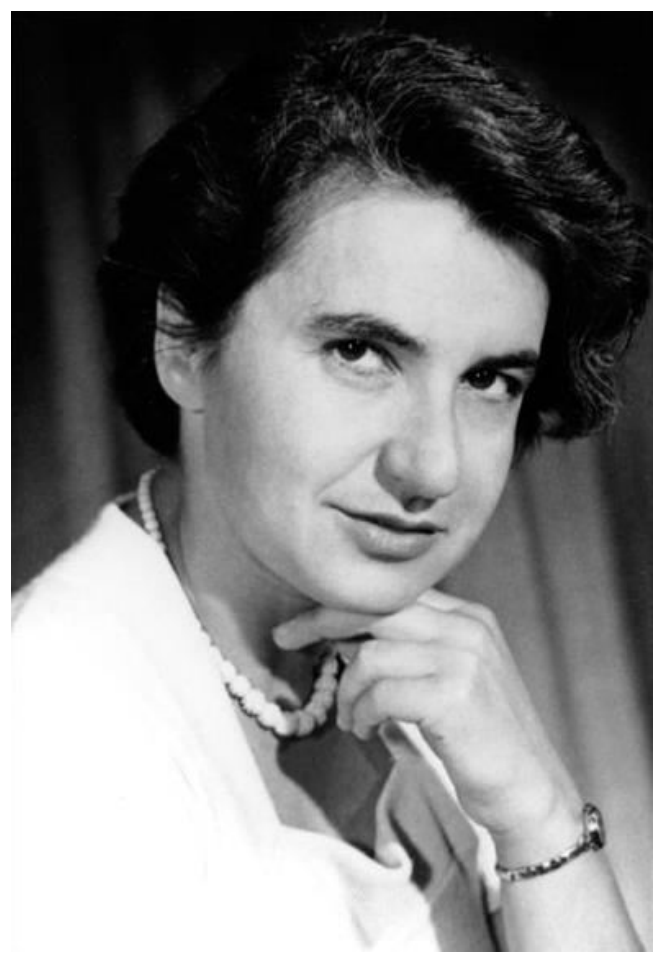

Figure 11. Rosalind Elsie Franklin, in the 1950's. Photo by Peter Fisher. Copyright Birkbeck, University of London ${ }^{42}$

After finishing her undergraduate studies, Rosalind had the chance to do research in a government laboratory. It was the British Coal Utilisation Research Association (BCURA). ${ }^{53}$ In 1945, Rosalind Franklin presented her thesis on coal and related materials and sent her first paper for publication.

In Paris, Jacques Mering, a Jewish scientist of Russian origin, was in charge of the Laboratoire Central des Services Chimiques de L'État, the "Labo". Rosalind spent almost four happy years working in his team. She successfully learns how to use the X-ray diffraction technique in order to attain maximum knowledge on the internal organization of crystals and of "cluttered" amorphous substances. The use of monochromatic radiation and the specific nature of the angle focus had rendered French investigation one of first quality. Rosalind feels more at home than she ever felt in England. She even takes up Christian Dior's New Look...

Later, Rosalind Franklin sails to King's College in London to work with John Randall. ${ }^{54}$ Randall's first suggestion was that Rosalind's research should focus on the study 
of proteins by X-ray diffraction. However, he changes his mind as to where this research project leads: It now seems that it would be a good deal more important for you to investigate the structure of certain biological fibers". He refers to nucleic acids and to DNA in particular. ${ }^{24,25}$

Maurice Wilkins was also in King's College. ${ }^{55} \mathrm{He}$ had graduated at Cambridge and later worked under Randall at Birmingham and St. Andrews Universities. When Randall opened the research unit at King's he assigned Wilkins to his team who thought that Rosalind was going to be his qualified assistant. Randall had a convoluted mind. He "forgot" to tell Rosalind what role Wilkins would play in the scheduled research and also "forgot" to tell Wilkins that Rosalind was an accredited researcher with five years of valuable post-doctoral work and because of this she could not be a mere assistant. A fourth element, Raymond Gosling, the "PhD slave boy" also played an important role in this story, since his research depended on the choices of the three others. ${ }^{56}$

While working with Wilkins, Gosling had already realized that the nucleic acid provided by Rudolf Signer generated excellent X-ray diffraction images. ${ }^{57}$ The images were stunning, the first true indicators that DNA had an ordered crystalline structure; furthermore, the spots seemed to make up an $X$ shape. But this $X$ was not enough to draw conclusions on the structure. They needed to go further and employ more sophisticated equipment like the one Rosalind had used in Paris. This equipment was ordered with all recommended specifications.
Wilkins felt he had been transcended. His relationship with Rosalind started deteriorating. One should emphasize that she was 30 years old and Maurice 35 . She was a single, intelligent, elegant girl with a pair of "beautiful black eyes". No love affairs where known to her. Maurice was tall, gentle and attractive. He was going through a divorce from an American wife who had stayed in the USA with their son and, therefore, he was needy of affection. All these facts would presume a romantic atmosphere between them. But there wasn't.

Wilkins feels frustrated and shares his frustration with his long-standing friend Francis Crick. ${ }^{58,59}$ They had both worked at the British Admiralty during World War II. Together with James Watson, ${ }^{60}$ Crick was now working at the Cavendish Laboratory directed by Lawrence Bragg. As no one is doing research on DNA, here Wilkins feels at ease to tell about the developments attained with this molecule. Everything Crick hears is passed on to Watson. Did I say too much?, Wilkins asks himself when returning to London.

Rosalind and Gosling discovered that there were two types of DNA. When hydrated it stretched and its diameter decreased. When dry it retracted. Difficulty in reading $X$-ray diffraction photographs was due to the fact that these two types of DNA frequently existed together. Therefore, the dry crystalline DNA was designated as A-type (A-DNA) and the hydrated, paracrystalline one was designated as B-type (B-DNA). Rosalind was able to obtain separate and sharp diagrams of these two sequences. 

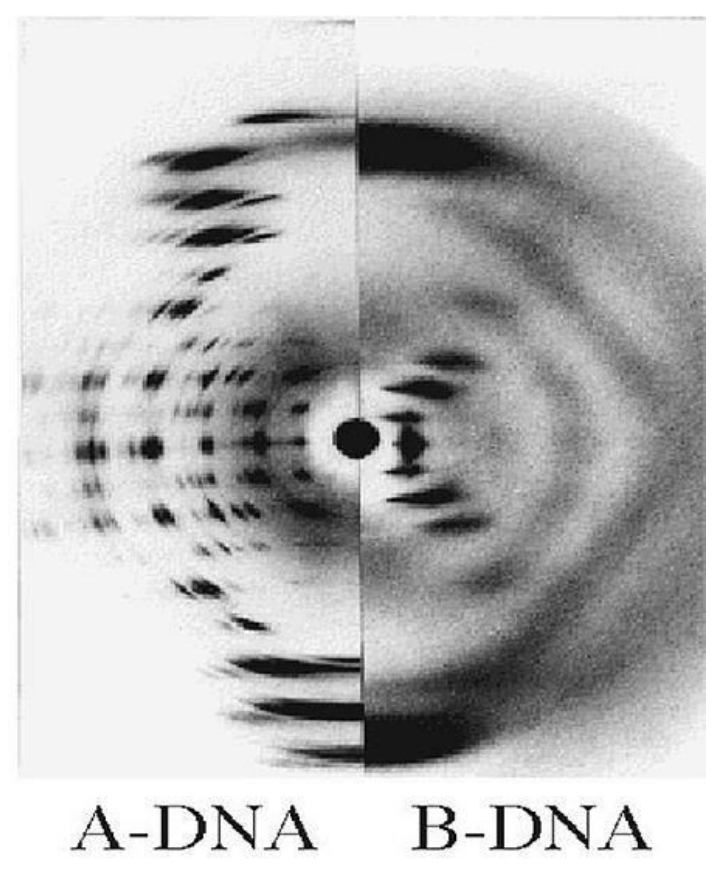

Figure 12. A- and B-DNA X-ray diffraction patterns. Photo by I.C. Baianu et al. ${ }^{62}$

Rosalind was essentially a physical chemist, a crystallographer; she is drawn to the quantitative aspect, the parameter values of the crystal lattice, to the identification of the molecule's crystallization system. Furthermore, she considers it to be unwise, even non-scientific, to advance any proposal of a structural character without solid verification of all data regarding the molecule. As to the biological functions of nucleic acids, their genetic activity, this was a matter that only vindicated a later research... Rosalind will soon attain all required data. A methodic and systematic research will allow her to determine the dimensions of the molecule's unit and its type of packaging, and to place phosphate groups and even base groups. Dorothy Hodgkin helps her out with the resolution of the crystal's spatial group. Dorothy was profoundly impressed with the quality of Rosalind's research. The X-ray images obtained by Rosalind and Gosling required an exposition time of 100 hours. A photograph took by them between the 1st and the 2nd of May 1952 will go down in the history of science as a very important one the famous crystal clear "Photo 51 " of BDNA. A central cross, an $X$ irradiating from the center with nothing else. Structurally speaking it is undoubtedly a helix. ${ }^{62}$

In December 1951 King's is visited by the Biophysics Unit of the Medical Research Council's evaluation committee. Max Perutz, Crick's supervisor in Cambridge, is one of its members. Research group members prepared a report on the ongoing research. Rosalind provides a thorough description of all DNA characteristics. In her report she includes information that had not yet been published. However, "Photo 51" is not listed in her report. 


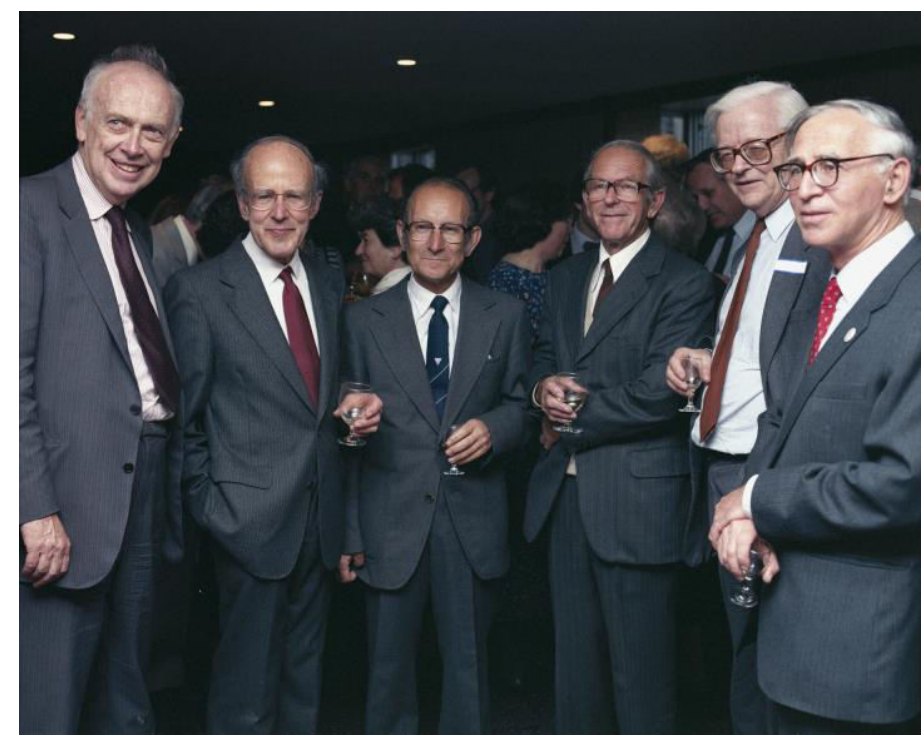

Figure 13. Group of LMB Nobel Laureates - James Watson, Max Perutz, César Milstein, Fred Sanger, John Kendrew and Aaron Klug - at the $40^{\text {th }}$ anniversary celebrations of LMB. Courtesy of MRC Laboratory of Molecular Biology, Cambridge, UK

Lawrence Bragg was the big boss at the Cavendish Laboratory. On Watson and Crick's request he authorizes them to order the necessary components to build a three dimensional DNA model. At Cavendish, on March the 7th, Watson and Crick completed the double helix model. ${ }^{63,64}$ The manner in which Randall and Bragg agreed to disclose information on their discovery overshadowed Rosalind. Furthermore, it tampered with the true ongoing of the research. The agreement included the publication of three papers in Nature under the common title Molecular Structure of Nucleic Acids. All experimental research that had preceded the model had been developed at King's. Nevertheless, the first paper, the one displaying the model design, belongs to Crick and Watson and it distinctively states: "We were not aware of the details of the results presented there (referring to the two articles Rosalind had recently sent to publication) when we devised our structure..." ${ }^{65}$ This is a truth that sounds like a lie. Worse still, Rosalind was forced to introduce a modification in her paper. Where one could previously read "our fundamental findings", now was changed into "our general ideas are not inconsistent with the model proposed by Watson and Crick in the preceding communication..." integrates this paper. ${ }^{66}$

Rosalind was not happy at King's College. She was accepted by John Bernal's group at Birkbeck and lets Randall know she is leaving. It is not known if the decision to leave was taken solely by her or if she was pushed by Randall to do so. Later, at Birkbeck College, Rosalind was happy again. The conditions she worked in were far worse than those at King's but here "she could breath". Her merit was recognized, her boss was the "Sage". She will be side by side with Aaron Klug, her most cherished friend and co-worker. X-Ray diffraction crystallography, her specialty, shall be put to use in the study of nucleic acids in the tobacco mosaic virus. 

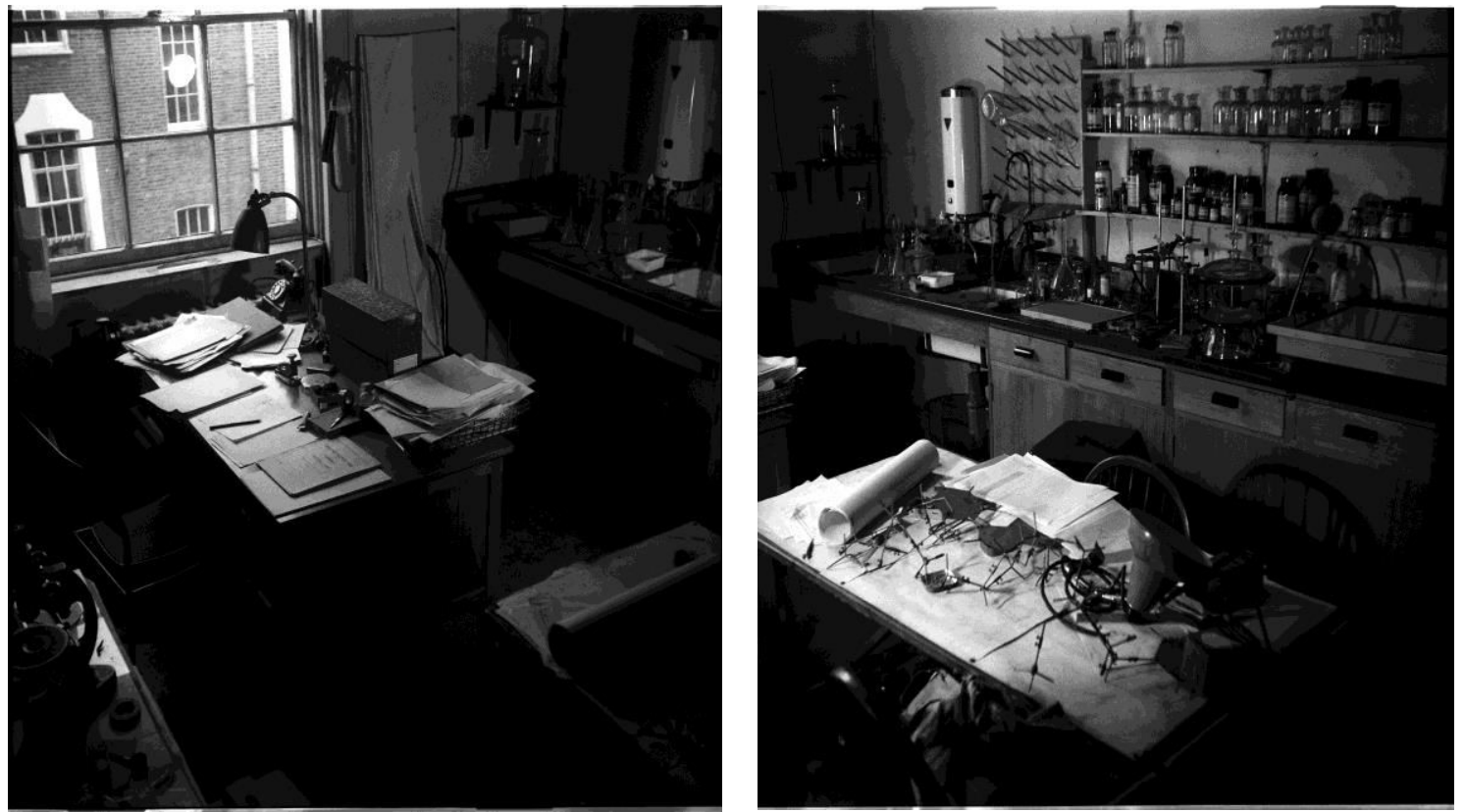

Figure 14. Desk and Laboratory of Rosalind Franklin at Birkbeck College London. Browse The Collection. Courtesy of John Finch/MRC Laboratory of Molecular Biology, Cambridge, UK

Her scientific pilgrimage took her twice to the United States were she held conferences in several cities. Rosalind's lectures not only focused on the research carried out in Paris on carbon structure and its various manifestations, but also dealt with her research on DNA structure. As much as she had loved Paris, she also loved the United States and the way in which her work was respected and cherished.

She was but 37 years old when she died of ovarian cancer. It was much too early. Rosalind Franklin's posthumous reputation soared. In 1962 her research on DNA attained its utmost recognition when James Watson, Francis Crick and Maurice Wilkins were awarded the Nobel Prize of Physiology or Medicine "for their discoveries concerning the molecular structure of nucleic acids and its significance for information transfer in living material". ${ }^{68}$ The same Nobel Prize can only be assigned to a maximum of three living scientists. One may speculate... Would they have received it if Rosalind were alive? Would it have been awarded? ${ }^{69}$ In 1998 Rosalind's portrait was put up alongside with Wilkins' at The National Portrait Gallery in London. In 2004 Chicago Medical School, founded in 1912, changed its name into
Rosalind Franklin University of Medicine and Science, thus paying a tribute to perseverance and dedication to discovery, and unfolding a future pathway for upcoming students. ${ }^{70}$

\section{The "curly haired" Israeli crystallographer - Ada E. Yonath}

The fourth woman to receive the Nobel Prize in Chemistry was the Israeli Ada E. Yonath, once again through research in $\mathrm{X}$-ray crystallography. ${ }^{26}$ By this method she enabled solving the sought after structure of ribosomes. Ada was born in Jerusalem but her Jewish parents who initially lived in Poland immigrated to Palestine in 1933. She had a difficult youth but never once gave up on her training goals. ${ }^{71-74}$

With a first graduation in Science and an MSc in Biochemistry from the Hebrew University of Jerusalem, she received her doctorate at the highly respected Weizmann Institute of Science, in Israel. Her scientific research also led her to the Carnegie Mellon University (CMU) and to the Massachusetts 
Institute of Technology (MIT) in the United States of America. The main topic of her research has been the understanding of the mechanisms

synthesis.

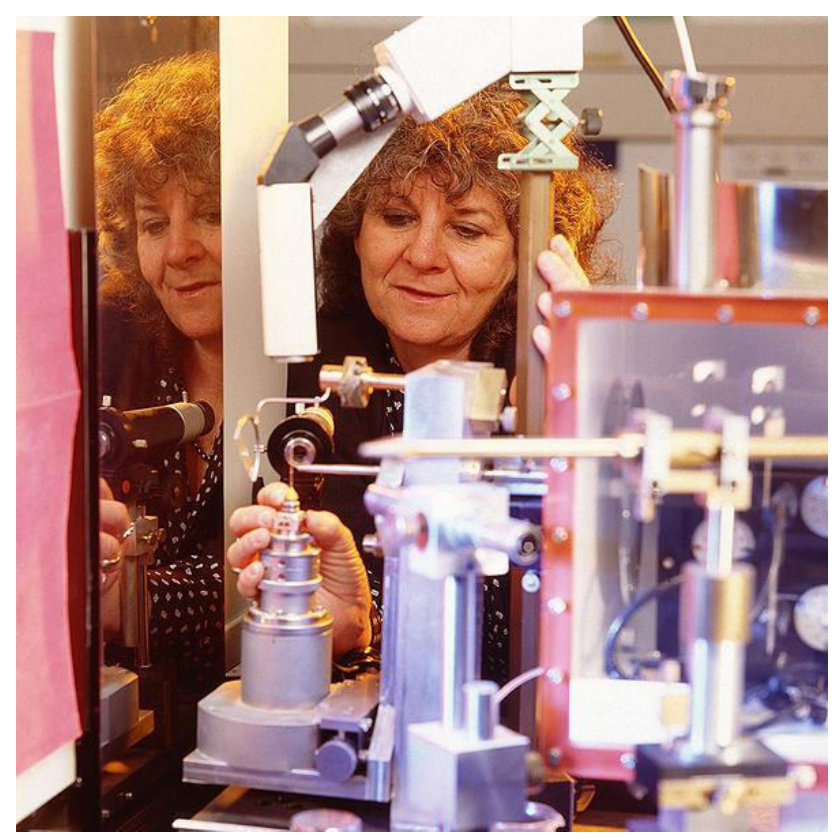

Figure 15. Ada Yonath in the Weizmann Institute of Science. Photo by Miki Koren, Weizmann Institute of Science ${ }^{74}$

Thus, and against the scientific community's general opinion, Ada's goal became decoding the tridimensional structure of ribosomes, the so complex molecules essential to life. They are composed by sub-units that are in constant change inside the cells, which when in close connection with RNA (ribonucleic acid) generate sequences of protein amino acids. They translate the protein genetic code. But how can one crystallize a molecule that is not only in constant metamorphosis but also deteriorates easily? ${ }^{76}$

Ada Yonath thought of the polar bears! During winter the vital functions of polar bears "fall asleep" and their ribosomes are "immobilized". When applied to resistant bacteria in extreme stress, this idea allowed the crystallization of their ribosomes and also their analysis by X-rays. Eureka! But it took Ada 20 years to achieve her first results... "Those who laughed at me became my competitors" - this is how she describes the recognition she finally won for a lifetime of work. ${ }^{77}$

In 2006, Ada Yonath was the winner of Wolf Prize in Chemistry. ${ }^{79}$ In 2009, together with Venkatraman Ramakrishnan and Thomas Steitz, Ada received the Nobel Prize in Chemistry - for studies of the structure and function of the ribosome. ${ }^{26}$ Hopefully this research will hereafter enable the development and design of new antibiotic drugs aimed to block the harmful actions of bacterial ribosomes. 


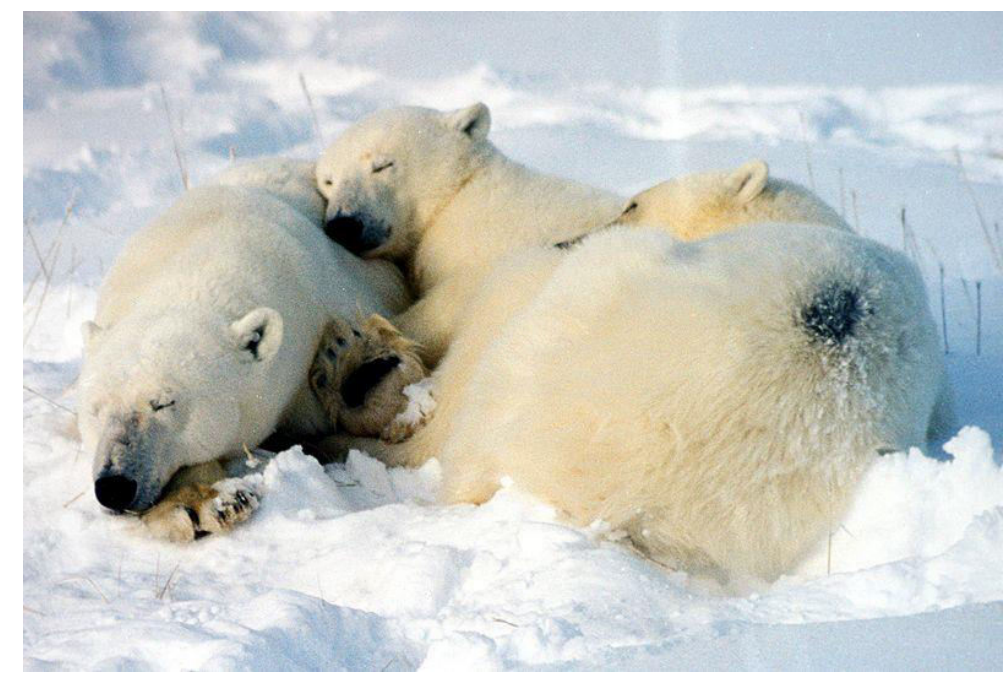

Figure 16. Polar bears in a lethargic state in Churchill (Hudson Bay, Canada). Photo by Brocken Inaglory ${ }^{78}$
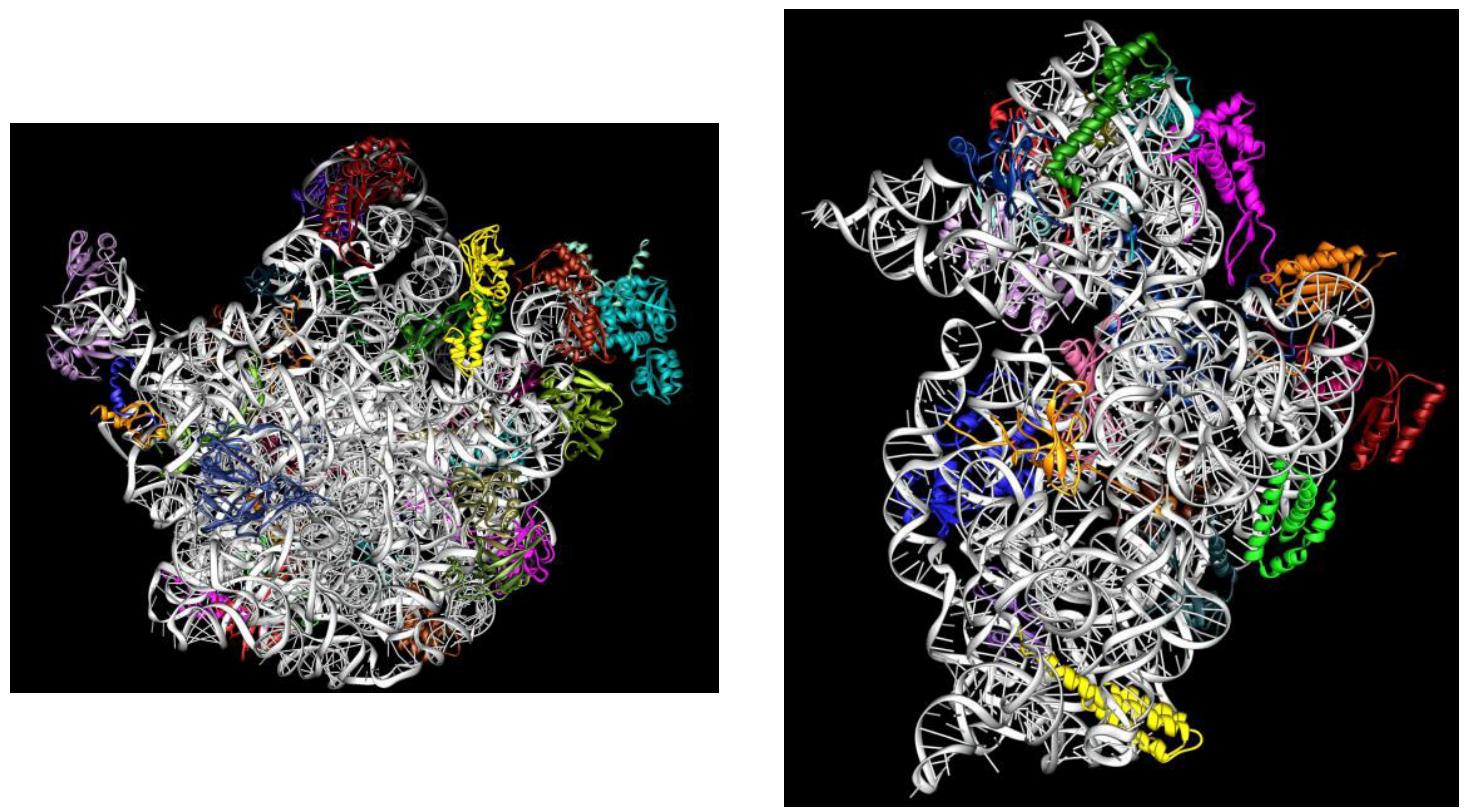

Figure 17. The $3 \mathrm{~A}$ structures of the two ribosomal from eubacteria subunits (white RNA on black background). Left: The large ribosomal subunit from Deinococcus radiodurans (D50S); Right: The small ribosomal subunit from Thermus thermophilus (T30S). Courtesy of Ada E.

Yonath and Joerg Harms

\section{Final Comments}

The continuous improvement of experimental methods, new technologies and mathematical functions, as well as the emergence of calculating machines, opened the possibility to explore accurately the three-dimensional structures of macro biomolecules. Most biomolecular structures are determined by X-ray crystallography. ${ }^{80}$ Knowledge of the location of atoms, bond angles and distances between them allowed determining active centers, understanding functionality and thus creating new effective 
drugs.

Dorothy Hodgkin and Rosalind Franklin were physical chemists. However, their research data and interpretations were crucial to the development of molecular biochemistry. The determination of the detailed structure of ribosomes by Ada Yonath has been important in understanding the basic function of living cells. This knowledge can be put to a practical use, since many antibiotics can cure diseases by blocking the function of bacterial ribosomes.

Dorothy and Rosalind were distinguished scientists. They were self-sufficient. These women showed persistence. They were stubborn and they believed. They were perfect in everything they undertook. John Bernal described Rosalind as the person whose "photographs are among the most beautiful $X$-ray photographs of any substance ever taken".81,82 Tom Blundell said about Dorothy that she was "an intuitive scientist, having a great gift for identifying important problems in chemistry and biology and devising new methods of solving them using crystallography. She was a warm and supportive research leader who treated her research team as an extension of her family". ${ }^{23}$

These women achieved international reputation and became feminist icons. For them, science gave a partial explanation of life and they enjoyed life, very much. However, at the same time, they loved traveling, to raise a family, to chat with friends... They loved clothes and good food... They had a strong political conscience. By defying conventions and overcoming them they left us an invaluable testimony. They were brilliant, exciting persons in different ways. Undoubtedly, Ada Yonath bears the same high standards.

So far, only four women received the Nobel Prize for Chemistry and curiously there is a strong liaison between their scientific goals. ${ }^{83}$ Their research was focused on radiation and matter, on the breaking of atoms and the discovery of new atoms, on the knowledge of molecules, their atomic and spatial structure and their function. This progress in scientific knowledge was a ruling thematic throughout the $20^{\text {th }}$ century having had surprising outcomes of great use. And this shall go on.

\section{References}

${ }^{1}$ Website Wikimedia Commons about Wilhelm Röntgen. Available in: $<$ http://commons.wikimedia.org/wiki/File:Fir st medical $X$ -

ray by Wilhelm Röntgen of his wife Anna Bertha Ludwig\%27s hand -

18951222.gif>. Accessed: 12 September 2012.

${ }^{2}$ Gonçalves-Maia, R., O Legado de Nobel Perfis na Ciência do Século XX (1900-1959), Escolar Editora: Lisboa, 2008. ISBN 978-972592-228-6.

${ }^{3}$ Hargittai, I., The Road to Stockholm. Nobel Prizes, Science, and Scientists, Oxford University Press: New York, 2002. ISBN 0-19850912-X.

${ }^{4}$ Jensen, P.W.; Palenik, G.J.; Suh, il-H., The History of Molecular Structure Determination Viewed through the Nobel Prizes, J. Chem. Ed., 2003, 80(7), 753-761.

${ }^{5}$ Official website of the Nobel Prize: Wilhelm Conrad Röntgen. Available in: <http://www.nobelprize.org/nobel prizes/ph ysics/laureates/1901/rontgen-bio.html>.

Accessed: 12 September 2012.

${ }^{6}$ Official website of the Nobel Prize: Max von Laue. Available in: <http://www.nobelprize.org/nobel_prizes/ph ysics/laureates/1914/>. Accessed: 12 September 2012.

${ }^{7}$ Websites Wikimedia Commons about Wilhelm Röntgen and Max von Laue. Available in: $<$ http://commons.wikimedia.org/wiki/File:Wi lhelmRöntgen.JPG?uselang=pt $>\quad$ and $<$ http://commons.wikimedia.org/wiki/File:M 
ax von Laue 1914.jpg>. Accessed: 12 September 2012.

8 Jenkin, J., William and Lawrence Bragg, father and son, Oxford University press: New York, 2008. ISBN 978-0-19-923520-9.

${ }^{9}$ Official website of the Nobel Prize: William Henry Bragg, William Lawrence Bragg. Available in: <http://www.nobelprize.org/nobel_prizes/ph ysics/laureates/1915/>. Accessed: 12 September 2012.

${ }^{10}$ Websites Wikimedia Commons about William Bragg and Lawrence Bragg. Available in:

<http://commons.wikimedia.org/wiki/File:W h-bragg.jpg > and <http://commons.wikimedia.org/wiki/File:Wl -bragg.jpg>. Accessed: 12 September 2012.

11 Patterson, A. L., Experiences in Crystallography - 1924 to Date (Personal Reminiscences), in 50 Years of X-ray Diffraction, Biographical notes on individual crystallographers, IUCr. Available in: <http://www.iucr.org/people/crystallographe rs> and <http://www.iucr.org/ data/assets/pdf file /0003/777/patterso.pdf $>$. Accessed: 12 September 2012.

12 Marsh, R. E.; Shoemaker, D. P., Obituary Arthur Lindo Patterson, 1902-1966, in Acta Crystallographica, IUCr, Biographical notes on individual crystallographers, IUCr. Available in:

<http://www.iucr.org/people/crystallographe rs $>$ and <http://journals.iucr.org/q/issues/1967/05/0 0/a05543/a05543.pdf>. Accessed: 12 September 2012.

13 Bernal, J. D.; Crowfoot, D. Nature 1934, 133, 794. [CrossRef]

${ }^{14}$ Bernal, J. D. - Birkbeck History. Available in: $<$ http://luna-

insight.smith.edu:8180/luna/servlet/BIRKBEC KBCM 11 11>. Accessed: 12 September 2012.

${ }^{15}$ Brown, A., J. D. Bernal - The Sage of Science, Oxford University Press: New York, 2005. ISBN 0-19-851544-8.
${ }^{16}$ Perutz, M. F., Molecular Biology in Cambridge in Cambridge Scientific Minds, ed. Harman, P.; Mitton, S., Cambridge University Press: Cambridge, 2002. ISBN 0-521-786126.

17 Bernal, J. D., A Life in Science and Politics, ed. Swann, B.; Aprahamian, F, Verso Books: London, 1999. ISBN 978-1859848548.

${ }^{18}$ Ferry, G., Max Perutz and the Secret of Life, Chatto \& Windus: London, 2007. ISBN 9780701176952.

${ }^{19}$ Official website of the Nobel Prize: Max Ferdinand Perutz. Available in: <http://www.nobelprize.org/nobel_prizes/ch emistry/laureates/1962/>. Accessed: 12 September 2012.

${ }^{20}$ Official website of the Nobel Prize: Aaron Klug. Available in: <http://www.nobelprize.org/nobel prizes/ch emistry/laureates/1982/>. Accessed: 12 September 2012.

${ }^{21}$ Contributions of $20^{\text {th }}$ Century Women to Physics - Crystallography. Available in: <http://cwp.library.ucla.edu/> Accessed: 12 September 2012.

${ }^{22}$ Ferry, G., Dorothy Hodgkin - A Life, Granta Books: London, 3th ed., 1999. ISBN 1-86207285-X.

${ }^{23}$ Gonçalves-Maia, R., Dorothy Crowfoot Hodgkin - Pepsina, Penicilina, Colesterol, Vitamina $B_{12}$, Insulina, Edições Colibri: Lisboa, 2010. ISBN 978-972-772-991-3.

${ }^{24}$ Maddox, B., Rosalind Franklin - The Dark Lady of DNA, Harper Collins Publishers: London, 2003. ISBN 0-00-655211-0.

${ }^{25}$ Sayre, A., Rosalind Franklin and DNA, W. W. Norton \& Company Ltd.: New York, 1975. ISBN 0-393-32044-8.

${ }^{26}$ Official website of the Nobel Prize: Venkatraman Ramakrishnan, Thomas A. Steitz, Ada E. Yonath. <http://www.nobelprize.org/nobel prizes/ch emistry/laureates/2009/>. Accessed 12 September 2012.

${ }^{27}$ Vargas, M. D. Rev. Virtual Quim 2012, 4, 85.

[Link] 
${ }^{28}$ The History of the University of Oxford, vol. VIII: The Twentieth Century, ed. Harrison, B., Oxford University Press: Oxford, 1994. ISBN 0-19-822974-7.

${ }^{29}$ Himetop - The History of Medicine Topographical Database. Available in: $<$ http://himetop.wikidot.com/dorothycrowfoot-hodgkin-s-bust>. Accessed: 12 September 2012.

${ }^{30}$ Breaking Ground - Women in Old World Archaeology. Grace Crowfoot, E. Crowfoot. Available in: $<$ http://www.brown.edu/Research/Breaking Ground/results.php?d=1\&first=Grace\&last $=C$ rowfoot>. Accessed: 12 September 2012.

${ }^{31}$ The Palestine Exploration Fund - John Winter Crowfoot, 1873-1959. Available in: $<$ http://www.pef.org.uk/profiles/johnwinter-crowfoot-1873-1959>. Accessed: 12 September 2012.

${ }^{32}$ Dorothy Crowfoot Hodgkin - A Founder of Protein Crystallography. Available in: $<$ http://www.sdsc.edu/ScienceWomen/hodg kin.html>. Accessed: 12 September 2012.

${ }^{33}$ Rayner-Canham, M.F.; Rayner-Canham, G.W., Women in Chemistry: Their Changing Roles from Alchemical Times to the MidTwentieth Century, Chemical Heritage Foundation: Philadelphia 2005. ISBN 9780941901277.

${ }^{34}$ Rickes, E.L.; Brink, N.G.; Koniuszy, F.R.; Wood, T.R.; Folkers, K. Science 1948, 107, 396. [CrossRef] [PubMed]

${ }^{35}$ The X-Ray Analysis of Complicated Molecules, D. C. Hodgkin, Nobel Lectures, 11 December 1964, Stockholm Concert Hall. Available

$<$ http://gos.sbc.edu/h/ch/ch.html $>$.

Accessed: 12 September 2012.

${ }^{36}$ Websites Wikimedia Commons about Cholesterol, Penicillin and Cobalamin. Available in: $<$ http://commons.wikimedia.org/wiki/File:Ch olesterol.svg>; $<$ http://commons.wikimedia.org/wiki/File:Pe nicillin-G.png>

and
<http://commons.wikimedia.org/wiki/File:Co balamin.png>. Accessed: 12 September 2012.

${ }^{37}$ Official website of the Nobel Prize: Dorothy Crowfoot Hodgkin. Available in: <http://www.nobelprize.org/nobel_prizes/ch emistry/laureates/1964/>. Accessed: 12 September 2012.

${ }^{38}$ Dodson, G., Dorothy Mary Crowfoot Hodgkin, O. M. 12 May 1910 - 29 July 1994, Biographical Memoirs of Fellows of The Royal Society, 2002, 48, 179-219.

${ }^{39}$ Farago, P. J. Chem. Ed. 1977, 54, 214. [CrossRef]

${ }^{40}$ British woman wins Nobel Prize $-£ 18,750$ award to mother of three. 29 Oct. 1964.

${ }^{41}$ Nobel Prize Winner is a Grandmother, The New York Times, 30 Oct. 1964.

42 J. D. Bernal and Dorothy Hodgkin Birkbeck History. Available in: <http://lunainsight.smith.edu:8180/luna/servlet/BIRKBEC KBCM 11 11>. Accessed: 12 September 2012.

${ }^{43}$ Dodson, G.; Whittingham, J. L., Insulin: Sequence, Structure and Function - A Story of Surprises in Insulin \& Related Proteins Structure to Function and Pharmacology, pp. 29-39, eds. Federwisch; M, Dieken; M. L.; De Meyts, P., Springer, 2002. ISBN 978-1-40200655-5.

${ }^{44}$ Vijayan, M. Curr. Sci. 2002, 83, 1598. [Link]

${ }^{45}$ Collected Works of Dorothy Crowfoot Hodgkin, ed. Dodson, G.G.; Glusker, J.P.; Ramaseham; S.; Venkatesan, K., Indian Academy of Sciences: Bangalore, vol. 1-3, 1996. ISBN 81-7296-020-4.

${ }^{46}$ Howard, J. A. K. Nat. Rev. Mol. Cell Biol. 2003, 4, 891. [CrossRef]

${ }^{47}$ Chemical Achievers. The Human Face of the Chemical Sciences - Dorothy Crowfoot Hodgkin. Available in: $<$ http://www.chemheritage.org/classroom/c hemach/pharmaceuticals/hodgkin.html>.

Accessed: 12 September 2012.

${ }^{48}$ DiGiovani, D., Dorothy Crowfoot Hodgkin The British Chemist with a Worldwide

Rev. Virtual Quim. |Vol 4| |No.6| |818-839| 
Perspective.

Available

in:

<http://www.suite101.com/article.cfm/biogr aphies scientists/97240/1>. Accessed: 12 September 2012.

${ }^{49}$ Glusker, J. P., Dorothy Crowfoot Hodgkin (1910-1994) in Out of the Shadows Contributions of Twentieth-Century Women to Physics, ed. Byers, N.; Williams, G., Cap. 22, Cambridge University Press: Cambridge, 2006. ISBN 0-521-82197-5.

${ }^{50}$ Cohen, L. J., Dr. Dorothy Crowfoot Hodgkin: Chemist, Crystallographer, Humanitarian (1910-1994). Available in: <http://www.almaz.com/nobel/chemistry/dc h.html>. Accessed: 12 September 2012.

51 Pugwash - Conferences on Science and World Affairs. Available in: <http://www.pugwash.org/reports/pim/hodg kin.htm>. Accessed: 12 September 2012.

52 Glynn, J., My Sister Rosalind Franklin, Oxford University Press: New York, 2012. ISBN 978-0-19-969962-9.

53 Profiles in Science: The Rosalind Franklin Papers. Available in: <http://profiles.nlm.nih.gov/ps/retrieve/Coll ection/CID/KR>. Accessed: 12 September 2012.

54 King's College London - Our History. Available in:

<http://www.kcl.ac.uk/biohealth/research/di visions/randall/about/history/index.aspx>.

Accessed: 12 September 2012.

55 King's College London - DNA: the King's story. Available in: <http://www.kcl.ac.uk/depsta/iss/archives/d na/faq4-wilkins1.html>. Accessed: 12 September 2012.

${ }^{56}$ King's College London - DNA: the King's story. Available in: <http://www.kcl.ac.uk/depsta/iss/archives/d na/faq7.html>. Accessed: 12 September 2012.

57 King's College London - DNA: the King's story, Signer's DNA. Available in: <http://kingscollections.org/exhibitions/archi ves/dna/early-work/signer-dna>. Accessed: 12 September 2012.
${ }^{58}$ Olby, R., Francis Crick - Hunter of Life's Secrets, Cold Spring Harbor Laboratory Press: New York, 2009. ISBN 978-0-87969-798-3

${ }^{59}$ Ridley, M., Francis Crick: Discoverer of the Genetic Code, HarperCollins Publishers: London, 2006. ISBN 978-0-06-082333-7.

60 In May 1951, Maurice attends a congress on large molecules in Naples. It took place at the Stazione Zoologica di Napoli. In his lecture he explained how it was possible to obtain nucleic acids as crystals. By displaying a picture of DNA obtained by X-ray diffraction he further advanced that the knowledge of the tridimensional structure of these molecules could lead to the understanding of the gene's structure. It was there that he met for the first time the young post doctoral researcher James Watson, recently interested in genetics.

${ }^{61}$ Website Wikimedia Commons about DNA. Source: "Physical Chemistry of Foods", vol.2, Van Nostrand Reinhold: New York, 1994. Available in: <http://commons.wikimedia.org/wiki/File:AB DNAxrgpj.jpg>. Accessed: 12 September 2012.

${ }^{62}$ X-ray photographs of DNA, Life Science Foundation. Available in: <http://www.lifesciencesfoundation.org/prin ter events-

Xray photographs of DNA.html>. Accessed: 12 September 2012.

63 DNA: Secret of Photo 51, DVD, NOVA, 2007. Available in: <http://www.youtube.com/watch?v=0tmNf6 ec2kU\&feature=related $>$. Accessed: 12 September 2012.

64 DNA - The Secret of Life, PBS Documentary, 2012. Available in: <http://www.youtube.com/watch?v=mJd0tT FUki0\&feature=related $>$. Accessed: 12 September 2012.

${ }^{65}$ Moran, L.A., Sandwalk - The Watson \& Crick Nature Paper (1953). Available in: <http://sandwalk.blogspot.pt/2007/07/watso n-crick-nature-paper-1953.html>. Accessed: 12 September 2012. 
${ }^{66}$ Franklin, R. E.; Gosling, R. E. Nature, 1953, 171, 740. [CrossRef]

67 Moran, L. A., Sandwalk - The Franklin \& Gosling Nature paper (1953). Available in: <http://sandwalk.blogspot.pt/2007/07/frankl in-gosling-nature-paper-1953.html>.

Accessed: 12 September 2012.

${ }^{68}$ Official website of the Nobel Prize: Francis Harry Compton Crick, James Dewey Watson, Maurice Hugh Frederick Wilkins. Available in: <http://www.nobelprize.org/nobel_prizes/m edicine/laureates/1962/>. Accessed: 12 September 2012.

69 James Watson, Francis Crick, Maurice Wilkins, and Rosalind Franklin, Chemical Heritage Foundation. Available in: <http://www.chemheritage.org/discover/onli ne-resources/chemistry-in-

history/themes/biomolecules/dna/watsoncrick-wilkins-franklin.aspx>. Accessed: 12 September 2012.

${ }^{70}$ Rosalind Franklin University of Medicine and Science - Rosalind Franklin 1920 - 1958. Available in:

<http://www.rosalindfranklin.edu/RosalindFr anklin.aspx>. Accessed: 12 September 2012.

71 Official website of the Nobel Prize: Ada E. Yonath - Biographical. Available in: <http://www.nobelprize.org/nobel_prizes/ch emistry/laureates/2009/yonath.html>.

Accessed: 12 September 2012.

72 Weizmann Institute Of Science "The Ada Yonath Story", Amy Lawdaw Productions. Available in: <http://vimeo.com/17577913 http://vimeo.com/17577913>. Accessed: 12 September 2012.

${ }^{73}$ Hargittai, I.; Hargittai, M., Candid Science VI. More Conversations with Famous Scientists, pag. 388-401, Imperial College Press: London. 2006. ISBN-13: 978-1-86094693-3.

${ }^{74}$ Nobel Prize in Chemistry 2009 - Weizmann Institute of Science. Available in: <http://wis- wander.weizmann.ac.il/yonath-awarded-

nobel\#.UEMYMkSHqQk>. Accessed: 12 September 2012.

${ }^{75}$ Website Wikimedia Commons about Ada Yonath. Available in: <http://commons.wikimedia.org/wiki/File:Ad a_Yonath_Weizmann_Institute_of_Science.jp g>. Accessed: 12 September 2012.

${ }^{76}$ Ribosome Structure and Function, Prof. Ada E. Yonath Grou. Available in: <http://www.weizmann.ac.il/sb/faculty page s/Yonath/>. Accessed: 12 September 2012.

77 Dr. Ada Yonath - Nobel Prize Winner. Available in: <http://www.youtube.com/watch?v=Ue3Am b-A-P0>. Accessed: 12 September 2012.

${ }^{78}$ Website Wikimedia Commons about polar bears. Available in: <http://commons.wikimedia.org/wiki/File:M other_cubs.JPG >. Accessed: 12 September 2012.

${ }^{79}$ Ada Yonath Winner of Wolf Prize in Chemistry - 2006. Available in: <http://www.wolffund.org.il/index.php?dir=s ite\&page=winners\&cs=13\&language $=$ eng $>$.

Accessed: 12 September 2012.

${ }^{80}$ Goodsell, D. S. Nature Education 2010, 3, 39. [Link]

${ }^{81}$ Rosalind Elsie Franklin: Pioneer Molecular Biologist. Available in: <http://www.sdsc.edu/ScienceWomen/frankl in.html>. Accessed: 12 September 2012.

82 Rosalind Franklin - UCLA. Available in: <http://www.physics.ucla.edu/ cwp/Phase2/ Franklin, Rosalind@841234567.html>.

Accessed: 12 September 2012.

${ }^{83}$ Official website of the Nobel Prize - Nobel Prize Awarded Women. Available in: <http://www.nobelprize.org/nobel prizes/lis ts/women.html>. Accessed: 12 September 2012. 